\title{
REFERRING A CASE TO THE HIGHEST DIVISION OF THE SUPREME COURT IN THE CRIMINAL PROCEDURE LEGISLATION OF UKRAINE AND EUROPEAN COUNTRIES
}

\author{
Nazar Bobechko, Alona Voinarovych and Volodymyr Fihurskyi
}

Summary: 1. Introduction - 2. Grounds for referring the criminal proceedings for consideration by the higher-level structural division of the Supreme Court -3 . An exclusive legal problem and necessity for the development of law and the uniformity of law enforcement practice as grounds for the referral. -4 . The fault of the grounds and the procedure for referring the case for consideration by a higher-level structural division of the Supreme Court in the Ukrainian Criminal Procedure Code. -5 . The reasonableness of judgements on the referral of criminal proceeding for consideration by the joint chamber and the Grand Chamber of the Supreme Court - 6. Consistency of court practice of the structural divisions of the Supreme Court - 7. Conclusions

To cite this article: N Bobechko, A Voinarovych, V Fihurskyi'Referring a case to the highest division of the Supreme Court in the criminal procedure legislation of Ukraine and European countries' 2021 1(9) Access to Justice in Eastern Europe 143165. DOl: 10.33327/AJEE-18-4.1-a000050

To link to this article: https://doi.org/10.33327/AJEE-18-4.1-a000050

Submitted on 11 0ct 2020 / Revised 24 Dec 2021 / Approved 22 Feb 2021 / Published online: 01 Mar 2021 View data Submit your article to Access to Justice in Eastern Europe http://ajee-journal.com/submissions

\section{ACKOWLEDGMENTS}

Authors would like to express their gratitude to the reviewers for their help and for the English editor.

\section{CONFLICT OF INTEREST}

The authors have declared that no conflict of interest or competing interests exist. Prof. Nazar Bobechko serves as Member of the Scientific Advisory Board of the Supreme Court, despite this, he does not represent any views of this body in this particular research or bound by that. 


\title{
REFERRING A CASE TO THE HIGHEST DIVISION OF THE SUPREME COURT IN THE CRIMINAL PROCEDURE LEGISLATION OF UKRAINE AND EUROPEAN COUNTRIES
}

\author{
Bobechko Nazar \\ Dr. Sc. (Law), Prof. of the Department of \\ Criminal Procedure and Criminalistics, \\ Ivan Franko National University of Lviv, Ukraine \\ Voinarovych Alona \\ $\mathrm{PhD}$ (Law), Assoc. Prof. of the Department of \\ Criminal Procedure and Criminalistics, \\ Ivan Franko National University of Lviv, Ukraine \\ Fihurskyi Volodymyr \\ $\mathrm{PhD}$ (Law), Assoc. Prof. of the Department of \\ Criminal Procedure and Criminalistics, \\ Ivan Franko National University of Lviv, Ukraine
}

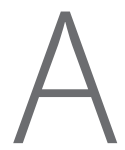

bstract The article aims to examine one of the elements of the formal mechanism of maintaining court practice unity in criminal proceedings of Ukraine and European countries - referring a case to the highest division of the Supreme Court. Similar to the Ukrainian criminal procedure legislation, the grounds for referring a criminal case and the procedure of its application are provided in the legislation of Estonia, Italy and Lithuania. At the same time, the Ukrainian legislator has established a number of special features, however, the wording of the relevant articles of the Criminal Procedure Code of Ukraine is not perfect. The article provides answers to such questions as how forceful the provisions of criminal procedure legislation of Ukraine are, to what extent of effectiveness the Supreme Court exercises its legal authority regarding the unity of court practice in criminal proceedings, and whether the controversies in legal positions of the structural divisions of the Supreme Court have been successfully avoided.

In order to achieve the stated aims, parts 2 and 3 are devoted to the examination of the grounds for referring a case in criminal proceedings of Ukraine and European countries. Part 4 outlines the shortcomings of the content of some articles of the Criminal Procedure Code of Ukraine concerning the procedure of the referral of a criminal case to the highest division of the Supreme Court. Part 5 provides the analysis of the validity of decisions made by the boards of judges at the Supreme Court on the referral of criminal proceedings to its higher judicial divisions - the joint chamber of the Criminal Cassation Court and the Grand Chamber of the Supreme Court. On the basis of the study of the judgements of boards, the judicial chambers of the Criminal Cassation Court and the Grand Chamber of the Supreme Court, in part 6 the question is answered on whether the Supreme Court of Ukraine managed to perform its duty on the assurance of court practice unity in such an area as criminal proceedings.

Keywords: exclusive legal problem, development of law, formation of uniform law enforcement practice, the Supreme Court, criminal proceedings, Ukraine. 


\section{INTRODUCTION}

In 2016, another judicial reform occurred in Ukraine. ${ }^{1}$ As a result, a number of provisions of Ukrainian legislation, including the criminal-procedural one, were redefined. Thus, the Supreme Court of Ukraine was liquidated, and the Supreme Court was established instead. ${ }^{2}$ In lieu of three higher specialized courts (for civil and criminal cases, commercial cases and administrative cases), four cassation courts were established (administrative, commercial, criminal and civil) which obtained the status of structural divisions of the Supreme Court. Joint chambers of these courts are supposed to develop common legal positions of boards of judges and judicial chambers. The Grand Chamber took the highest position in the hierarchical structure of the newly created Supreme Court.

The Ukrainian legislator moved away from the approach established by Roman law to the understanding of judicial power only as an interpreter and enforcer of the law ('Praxis judicum est interpres legum') by recognizing judicial precedent as the source of law. In such a manner, the judicial power, in person of the highest body in the judicial system of Ukraine, the Supreme Court, was granted authorities to formulate rules of conduct, along with the legislative and executive branches of power. Its activity is significantly important for the formation of a political regime of the state, and its decisions become a guideline for the equal application and the correct enforcement of rules of law as well as for the establishment of legal facts.

Deficiencies in criminal procedure legislation (gaps, conflicts, inconsistencies in legal regulation, erroneous use of blanket and reference norms, defects of the conceptual and categorical apparatus, ambiguity of language structures, etc.) and excessive use of evaluative concepts in regulations create judicial discretion. In turn, such discretion leads or may lead to different approaches to understanding the content and application of legal norms.

From the standpoint of the Consultative Council of European Judges (CCJE), permanence of conflicting judgments can create a state of legal uncertainty, thus reducing public confidence in the judiciary, which is one of the most important components of a state based on the rule of law. In such circumstances, the Supreme Court plays an important role in resolving inconsistencies in case law. ${ }^{3}$

By the way, in the items 37 and 63 of the judgment Beian v. Romania № 1, the European Court of Human Rights (ECtHR) noted that the role of the Supreme Court is, inter alia, to resolve inconsistencies in case law. ${ }^{4}$

1 M Zhernakov, 'Judicial Reform in Ukraine: Mission Possible?' (2016) 1:6-7 <http://en.dejure.foundation/ library/judicial-reform-in-ukraine-mission-possible> accessed 23 December 2020; C Giardullo, 'Four Years After: The 'Long March' of Justice-Sector Reforms in Ukraine' (2018) 1 (18) Istituto Affari Internazionali Papers 1: 9-11 <https://www.iai.it/sites/default/files/iaip1801.pdf> accessed 23 December 2020; S Nitsova, G Pop-Eleches, G Robertson, 'Revolution and Reform in Ukraine. Evaluating Four Years of Reform', Institute for European, Russian and Eurasian Studies at the George Washington University's Elliott School of International Affairs (2018) 1: 34-38<https://www.ponarseurasia.org/perspectives/ revolution-and-reform-ukraine-evaluating-four-years-reform> accessed 23 December 2020.

2 It should be recalled that on 15 December 2017 the new Supreme Court as the highest authority in the judicial system of Ukraine began its activities with freshly appointed judges (as of 23 December 2020, it had 183 judges from the maximum number of 200, specified by law), and the Supreme Court of Ukraine ceased its operation. The rebooting of the Supreme Court of Ukraine as a key part of judicial reform intended to purify the judiciary and establish fair justice in Ukraine.

3 Opinion No 20 (2017) of Consultative Council of European Judges (CCJE) 'The Role of Court with the Respect to the Uniform Aplication of the Law', items 6, $20<$ https://rm.coe.int/opinion-no-20-2017-onthe-role-of-courts-with-respect-to-the-uniform-a/16807661e3> accessed 23 December 2020.

4 Judgment of the European Court of Human Rights in Beian v Romania, No 1, 6 December $2007<$ https:// hudoc.echr.coe.int/eng\#\{\%22fulltext\%22:[\%22Beian\%20v.\%20Romania\%20\%E2\%84\%96\%201\%22], \%22documentcollectionid2\%22:[\%22GRANDCHAMBER\% 22,\%22CHAMBER\%22],\%22itemid\%22: [\%22001-83822\%22]\}> accessed 23 December 2020. 
The legal literature mainly covers issues related to the role of the Supreme Court in ensuring the unity and sustainability of judicial practice, the characteristics of judicial precedent in national legal systems. At the same time, such a formal mechanism - of ensuring judicial practice unity by referring a criminal case to a higher division of the Supreme Court - has not yet been covered in the comparative legal aspect.

The aim of this article is an examination of the grounds and the procedure of referring a case to the highest division of the Supreme Court in the criminal procedure legislation of Ukraine and European countries. In order to achieve the stated aim, the following tasks are set: to characterize the content of the grounds of a case referring to the highest division of the Supreme Court in the criminal procedure legislation of Ukraine and European countries, to disclose its procedure; to find out the motivation of the court decisions for referring a case to the highest division of the Supreme Court in the criminal procedure legislation of Ukraine; to identify the shortcomings in regulating of these issues in the criminal procedure legislation of Ukraine; and to clarify the consistency of a case law of the Supreme Court.

\section{GROUNDS FOR REFERRING THE CRIMINAL PROCEEDINGS TO THE HIGHER-LEVEL STRUCTURAL DIVISION OF THE SUPREME COURT}

For maintaining the unity of court practice, two grounds for referring criminal proceedings, for consideration, to the higher-level structural division of the Supreme Court are provided by the Criminal Procedure Code (CrPC) of Ukraine: 1) the necessity to deviate from the conclusion on the application of rule of law in similar relations, which was set out in an earlier decision of the higher-level structural division of the Supreme Court (parts 1-4 of Art. $\left.434^{1}\right)$; 2) the case contains an exclusive legal problem and such a referral is necessary for the assurance of development of law and formation of uniform law enforcement practice (part 5 of Art. 434 $).^{5}$ These grounds have been formulated with the help of evaluative concepts - 'similar legal relationships' and 'an exclusive legal problem'.

It should be noted that the introduction of these grounds is not a Ukrainian invention. The CCJE takes the view that numerous countries with Supreme Courts in civil law are now empowered to select cases with the intention of setting standards that should be applicable in future cases. Therefore, in these cases, a judgment of a Supreme Court, when it was reached with the intention to set a precedent, can already count as an authoritative case law. ${ }^{6}$

The legislation of some states does not establish the grounds for referring a criminal case but defines the conditions for accepting an appeal for consideration by the Supreme Court of these states.

Thus, according to section 323 of the Criminal Procedure Act of Norway (Straffeprosessloven), an appeal to the Supreme Court may not proceed without the consent of the Appeals Committee of the Supreme Court. Such consent shall only be given when the appeal is concerned with issues whose significance extends beyond the current case, or when other particularly important reasons indicate that the case should be tried in the Supreme Court. ${ }^{\text {? }}$

5 Code of Ukraine of 13 April 2012 No 4651-VI 'Criminal Procedure Code of Ukraine’ (as amended of 21 July 2020) <https://zakon.rada.gov.ua/laws/show/4651-17\#Text> accessed 23 December 2020.

$6 \quad$ Opinion No 20 (2017), (n) 2, item 14.

7 Law of Norway of 22 May 1988 No 25 'Criminal Procedure Act of Norway’ (as amended of 30 June 2006, No 53) <https://app.uio.no/ub/ujur/oversatte-lover/data/lov-19810522-025-eng.pdf> accessed 23 December 2020. 
In turn, item 1 of section 10 and section 11 of chapter 54 of the Swedish Code of Judicial Procedure (Rättegångsbalken) found that the Supreme Court, upon consideration of an appeal, should grant leave to appeal only if it is of importance for the guidance of the application of law. ${ }^{8}$

As a final point, the Code of Judicial Procedure of Finland (Oikeudenkäymiskaari) in section 2 of chapter 30a specifies that the Supreme Court may grant leave for an appeal for a precedent only if, in view of the application of the law in other similar cases or of the uniformity of legal praxis, it is important to submit the matter for a decision by the Supreme Court. ${ }^{9}$

In these countries a filtering system is established for cases before the Supreme Court. A criterion for filtering is whether a decision in this case would contribute to the development of the law. Given this, the Supreme Court is not obliged to deal with cases which do not warrant a decision by the highest court from a legal point of view. The purpose of this order is to enable the Supreme Court, given its limited resources, to shift its focus further onto the unity of law and the development of law. The use of these means will therefore have favourable consequences for these tasks of the Supreme Court. As a result, this court is in a position to focus its attention, above all, on those themes and problems which occur regularly in practice, and in respect of which there is a need for clear guidelines from the highest court. ${ }^{10}$

The existence of instruments for ensuring uniformity within the same court is particularly relevant for Supreme Courts. It is especially problematic if the Supreme Court itself becomes a source of uncertainty and of conflicting case law, instead of ensuring its uniformity. It is thus of paramount importance that within the Supreme Court mechanisms exist which can remedy inconsistencies within this court. Such instruments may include e.g. referrals to grand chambers or convening larger panels where the case law of the Supreme Court is divergent or where the reconsideration and possible overruling of an established precedent is considered. At least an 'exchange of opinions' with the chamber, from which case law another chamber intends to depart, might be necessary. ${ }^{11}$

Similar to Ukrainian criminal procedure, legislation grounds for referring a criminal case and the procedure of their application are provided in the legislation of Estonia, Italy and Lithuania.

For example, in item 1 of $\$ 356$ of the Code of Criminal Procedure of Estonia (Kriminaalmenetluse seadustik) this ground is formulated as:

the majority of the full panel of the Criminal Chamber reaches a different opinion than the legal principle or position hitherto held by the Supreme Court en banc on the application of law. ${ }^{12}$

Scholars note that cases may also be heard by special (ad hoc) panels composed of the members of different chambers or by the Supreme Court en banc. ${ }^{13}$

$8 \quad$ Law of Swedish of 18 June 1942 'The Swedish Code of Judicial Procedure’ (as amended of 12 January 2017) <https://www.government.se/49e41c/contentassets/a1be9e99a5c64d1bb93a96ce5d517e9c/theswedish-code-of-judicial-procedure-ds-1998_65.pdf> accessed 23 December 2020.

9 Law of Finland of 4/1734 'Code of Judicial Procedure of Finland' (as amended of 10 April 2015) <https:// www.finlex.fi/fi/laki/kaannokset/1734/en17340004_20150732.pdf> accessed 23 December 2020.

10 M Feteris, 'Development of the Law by Supreme Courts in Europe' (2017) 13(1) Utrecht Law Review 155: 156, 158, 159.

11 Opinion No 20 (2017) (n 2) item 24.

12 Law of the Republic of Estonia of 12 February 2003 'Code of Criminal Procedure of the Republic of Estonia' (as amended of 26 September 2013) <https://www.riigiteataja.ee/en/eli/530102013093/ consolide> accessed 23 December 2020.

13 J Laffranque, 'The Judicial System of Estonia and European Union Law' (2005) 33(2) International Journal of Legal Information 224: 228. 
Similarly, this ground is defined in part 2 of Art. 378 of the CrPC of Lithuania (Lietuvos Respublikos baudžiamojo proceso kodekso) whereby a cassation case heard by a panel of three judges may be referred to the plenary session of the Criminal Cases Division of the Supreme Court of Lithuania if the application of the Criminal or Criminal Procedure Law in the case would create grounds to deviate from the practice of the Supreme Court of Lithuania. ${ }^{14}$

The Supreme Court of Lithuania has noted that upon deciding the interpretation and application of law it is important to consider the factor of time i.e. it is essential to take into consideration that after the formulation of a certain rule both the interpreted rule and the court practice may change. Thus, any interpretation of the Supreme Court of Lithuania must be applied in the context of factual circumstances of the case, changes in law and the developments of court practice. In addition, in the case of conflict of precedents (when there are several different court decisions concerning analogous cases) the precedent of a higher instance should also be followed with consideration to the time of adoption and other significant factors (such as whether a precedent reflects the existing court practice or whether it is only a sporadic occurrence); the persuasion of the reasoning; the structure of the court (whether the decision has been made by a single judge or a chamber sitting in an extended composition or full court); whether the judges expressed separate opinions regarding a prior decision; important changes (social, economic and other) resulting from the decision of the court considered as precedent. ${ }^{15}$

Also, according to parts 1, 2 of Art. 618 of the Code of Criminal Procedure of Italy (Codici di procedura penale) should a chamber realize that the question of law under its examination has caused or may cause judicial conflict, it may, upon request of the parties or of its own motion, refer the appeal to the Joint Chambers of the Court of Cassation, by issuing an order. Should a chamber not share the principle of law affirmed by the Joint Chambers, it shall refer the decision on the appeal to the Joint Chambers of the Court of Cassation, by issuing an order. ${ }^{16}$ Researchers call this procedure a 'horizontal' precedent. ${ }^{17}$

In the deliberative moment, when the case is dealt with by a (simple) section, the problem of jurisprudential contrast may arise, in the sense that the question of law to be resolved has found different solutions in some simple sections or finds the judge deliberating on an interpretative position that is not in agreement with that of another simple section or of the same Joint Sections (criminal). In such cases the appeal is remitted by the same section to the United Sections for the decision in order to achieve a uniform interpretation of the law and to ensure the court practice. ${ }^{18}$

In the criminal procedure legislation of Ukraine, this is about the case when the board of judges, the chamber or joint chamber of the Cassation Court see different solutions to a typical legal situation in the criminal proceeding which came for a cassation hearing, compared to the one that has already formed a basis of a decision of the same instance,

14 Criminal Procedure Code of the Republic of Lithuania of 14 March 2002 No IX-785 'Lietuvos Respublikos baudžiamojo proceso kodekso' <https://e-seimas.lrs.lt/portal/legalAct/en/TAD/ TAIS.163482> accessed 23 December 2020.

15 D Ambrasienè and S Cirtautienè, 'The Role of Judicial Precedent in the Court Practice of Lithuania' (2009) 2(116) Jurisprudencija 61: 65.

16 Code of Criminal Procedure of Italy of 22 September 1988 No 477 'Codici di procedura penale' (as amended of 25 June 2020) <https://www.brocardi.it/codice-di-procedura-penale/libro-nono/titolo-iii/ capo-iii/art618.html $>$ accessed 23 December 2020.

17 L Baccaglini, G di Paolo, F Cortese, 'Judicial Precedent in the Italian Legal System: A Shift Toward a Stare Decisis Model?', (2017) Stanford Law School Chine Guiding Cases Project 1: 7 <https://cgc.law. stanford.edu/wp-content/uploads/sites/2/2017/04/CGCP-English-Commentary-19-Baccaglini-DiPaolo-Cortese.pdf $>$ accessed 23 December 2020.

18 Esplicato Codice Di Procedura Penale. XVIII edizione (Edizioni Giuridiche Simone 2013) 816. 
adopted in another board of judges, by this or another chamber, a joint chamber or the Grand Chamber of the Supreme Court (hereinafter - the SC Chamber).

The Ukrainian legislator is talking about the conclusion which is set out in a judgment made by the Supreme Court. However, the conclusion is neither a structural part of the ruling of the court of cassation instance nor a form of expression of court practice. From the semantic point of view, the term 'conclusion' means something that was decided by someone after a consideration of all information available. ${ }^{19}$ Such a final opinion, on the application of legal rules, is set out in the operative part of the ruling of the court of cassation instance. However, not only a logical outcome but also its argumentation which is given in the motivating part of the resolution, is important for law enforcement activity. Therefore, in parts 1-4 of Art. $434^{1}$ of the CrPC of Ukraine it is more appropriate to speak not about the conclusion, but the legal position of the court of cassation instance. The legal position of the Supreme Court in criminal proceedings is a point of view set out in a court ruling of the highest body in the judicial system of Ukraine on the basis of the results of review of justness of judgment. This position is mandatory when resolving similar cases regarding the interpretation of criminal and criminal procedural legal rules applicable to established circumstances of the case. It contains theoretically reasoned models of methods of legal conflicts resolution, overcoming of gaps in legal regulation, as well as established judicial rules, due to which the unity and stability of court practice is maintained.

An important question is the nature of the conclusions of the Supreme Court, or more precisely, the legal positions (pravovi pozytsii).

According to part 6 of Art. 13 of the Law of Ukraine 'On the Judiciary and the Status of Judges', conclusions about the application of rules of law outlined in court rulings of the Supreme Court are taken into consideration by other courts when applying such rules of law. ${ }^{20}$ The provision of such content is established in part 6 of Art. 368 of the CrPC of Ukraine: by choosing and applying the rule of law of Ukraine on criminal liability for socially dangerous acts when passing a sentence, the court shall take into account conclusions on the application of relevant rules of law set out in the court rulings of the Supreme Court. ${ }^{21}$

Shall the following provisions be understood as clarification of the binding power of legal positions of the highest authority in the judicial system of Ukraine?

In linguistics, the word 'consider' is interpreted as 'think about something very carefully, especially before making a decision; to think of someone or something in a special way or to have a special opinion.'2 ${ }^{22}$ This means that legal positions of the Supreme Court are not binding for lower-level courts; the latter should only take them into account when hearing and deciding on criminal proceedings.

Moreover, the obligation of taking into consideration applies only to legal positions of the Supreme Court regarding rule of law of Ukraine on criminal liability which is planned to be applied by the court of lower instance. Instead of this, legal positions of the highest court in the judicial system of Ukraine concerning the interpretation and application of criminal procedural rules may not be taken into account based on a lexical and grammatical interpretation of part 6 of Art. 368 of the CrPC of Ukraine.

In other words, adhering to legal positions of the Supreme Court is based on its authority which shall be formed.

19 Longman Dictionary of American English, spec. ed. (Pearson Education Limited 2009) 205.

20 Law of Ukraine of 13 April 2012 No 1402-VIII 'About the Court System and the Status of Judges' (as amended of 21 July 2020) <https://zakon.rada.gov.ua/laws/show/1402-19\#Text> accessed 23 December 2020.

21 Code of Ukraine (n) 4.

22 Longman Dictionary (n) 18, 213. 
This also concerns adherence to explanations of the Plenum of the Supreme Court on the application of legislation while deciding on court cases, which have recommendatory nature (item 10 of pt. 2 of Art. 46 of the Law of Ukraine 'On the Judiciary and the Status of Judges'.) ${ }^{23}$

However, classical case law is formed as a result of consideration by the court of higher instance of the particular case and is not established as a result of abstract generalizations of court cases in certain categories of cases. This specific nature 'from concrete to general' is affiliated with the professional duty of judges to administer justice which foresees obligatory sufficiency of court decisions.

From the perspective of the European Commission for Democracy through Law (Venice Commission), the procedure of formulating the provisions of court rulings of the Supreme Court of the Ukraine Plenum constitutes an extra-judicial measure that goes outside judicial proceedings and has the nature of an administrative ruling regarding the judgements of courts of a lower level. In such a manner, the principle of the independence of judges is violated, so this measure should not be used by the state in which that rule of law applies. The Commission considers that court rulings of the Plenum of the Supreme Court of Ukraine carry great risk as a ground for the cancelling of judgements under the procedure of supervision, grossly violating the principle of res judicata. ${ }^{24}$

Besides that, carrying out such kind of an abstract activity does not preclude mistakes being made in explanations that may be flawed, contradictory or nonconforming to law.

Despite the arguments mentioned, the Ukrainian legislator has saved relevant provisions in the new legislation about the court system but has refused to recognize explanations of the Plenum of the Supreme Court as binding.

The analysed provisions of the criminal procedure law of Ukraine use the evaluative term 'similar legal relations,' which is not disclosed by the Ukrainian legislator.

Such a question remains topical: by what features shall the term 'similarity' of legal relations be recognized - by the subject matter of legal regulation (criminal and criminal procedure), by the function in legal regulation (regulatory and protective), by nature (material and procedural), depending on the distribution of rights and obligations between subjects (unilateral and bilateral), by the correlation of rights and obligations of subjects (simple and complex), by the level of individualization of rights and obligations of subjects (absolute and relative), by the nature of responsibilities of subjects (active and passive), by composition (subject, object, content), by legal facts which form the basis for their occurrence, change or termination, etc.?

According to the established practice of the Supreme Court of Ukraine, similarity of legal relations means, in particular, the identity of the subjective composition of participants in relations, the object and subject matter of legal regulation, as well as conditions of application of legal rules (specifically, time, place, grounds of occurrence, termination and change of the corresponding legal relations). The content of legal relations is determined by the circumstances of each particular case in order to find out their similarity in different judgements of the court (courts) of cassation instance. ${ }^{25}$

23 Law of Ukraine (n) 19.

24 Opinion of European Commission for Democracy through Law on Draft Law of Ukraine on the 'Judicial System' (CDL (2001) 46) < http://www.venice.coe.int/webforms/documents/default. aspx?pdf=CDL(2001)055-e\&lang=RU\#> accessed 23 December 2020.

25 Judgment in case No 21-41a14 (The Supreme Court of Ukraine, 20.05.2014); Judgment in case No 444/2909/15 (The Supreme Court of Ukraine, 29 March 2017); Judgment in case No 910/3040/16 (The Supreme Court of Ukraine, 06 September 2017). 
However, such an interpretation is contrary to the semantic meaning of the words 'identical' and 'similar'. Thus, in linguistics 'identical' is interpreted as 'the same. ${ }^{26}$ Instead, 'similar' is defined as 'being almost identical, but not quite the same. ${ }^{27}$

The chance that the same legal situation exists with a different composition of criminal procedure relations is quite possible (for example, the denial to open an appeal proceeding on the appeal of an accused or another interested person who does not have a procedural status of participant in the criminal proceeding). Such cases require an individual approach.

Specific understanding of the sense of conditions of the application of legal rules is observed from the content of the foregoing legal position of the Supreme Court of Ukraine. The highest authority in the system of courts of general jurisdiction, in fact, has mixed different legal categories: requirements (conditions) for the application of legal rules, a first stage of the application of rules of law (making the base of findings for deciding the case - time, place and other circumstances) and the development of legal relations in particular cases (their occurrence, change or termination). For the law enforcement, it is too early to speak about the object of legal regulation.

The aforesaid position of the Supreme Court of Ukraine provides authentication between the concepts of the 'content of legal relations' and the 'essence of legal relations.' In the theory of law, most scholars relate the object, subject and essence to the content of legal relations. In such a manner the assessment of similarity of legal relationships is limited only to such an element as essence, neglecting other components of this category.

Considering the above, in our opinion, any legal relations with at least one common feature (for example, branch affiliation, character or function in legal regulation, legal fact underlying in their development, the rights and obligations of their subjects) are similar.

Therefore, the concept of 'similar relations' is extremely broad. The board of judges, chamber or joint chamber may well consider some relations to be similar while the others may not. How can this approach assure the unity of court practice?

It should be pointed out that in the context of parts $1-4$ of Art. $434^{1}$ of the CrPC of Ukraine for the referral of criminal proceedings for consideration of the Chamber, the Joint Chamber of Cassation Court and the Grand Chamber of the Supreme Court and hearing by them of this case, to establish similarity of legal relations is not enough. It is also necessary to 1) find out whether legal conclusion already formulated is relevant to legal relations which are the subject matter of the cassation hearing; 2) acknowledge wording of this conclusion by the corresponding supreme judicial division of the Supreme Court or the Supreme Court of Ukraine; 3) substantiate the necessity of change of the legal conclusion given the loss of validity or amendment of the legal rule which was applied while reaching such conclusion, inconformity with development of social relations, or noncompliance with public requirements. ${ }^{28}$

26 Longman Dictionary (n) 18, 507.

27 Ibid 18, 946.

28 Code of Ukraine (n 4). 


\section{AN EXCLUSIVE LEGAL PROBLEM AND THE NECCESSITY FOR THE DEVELOPMENT OF LAW AND THE UNIFORMITY OF LAW ENFORCEMENT PRACTICE AS GROUNDS FOR THE REFERRAL}

The criminal procedure legislation of other states defines some other ground for referring a criminal case to a higher division of the superior court.

Thus, in item $2 \S 356$ of the Code of Criminal Procedure of the Republic of Estonia, it is stated that a criminal matter is referred to the Supreme Court en banc if the majority of the full panel of the Criminal Chamber considers the adjudication of the criminal matter by the Supreme Court en banc to be essential for the uniform application of the law. ${ }^{29}$

In accordance with part 2 of Art. 610 of the Code of Criminal Procedure of the Italian Republic, the President of the Court of Cassation, either upon request of the Prosecutor General or the lawyers, or of his or her own motion, shall assign the appeal to the Court of Cassation to the Joint Chambers when the issues raised are particularly relevant or when conflicts among the decisions of individual chambers need to be solved. ${ }^{30}$ It is intended to encourage an adequate technical study of the legal problem. The aim of that order is to ensure the uniformity of the interpretation of the law, in line with the preventive function of the Court of Cassation. The sentences of the Joint Chambers are of particular importance within the legal system, precisely because they settle differences between Chambers once and for all, or because they take a position on a matter of particular importance. ${ }^{31}$

In turn, part 1 of Art. 378 of the CrPC of the Republic of Lithuania determines that a cassation case heard by a panel of three judges may be referred to an extended panel of seven judges if the proper application of the law of criminal or criminal procedure in the case would mean a new interpretation of a legal norm in case law. ${ }^{32}$

It seems that the Ukrainian legislator specified the above grounds for referring a criminal case, using the categories 'an exclusive legal problem', 'the development of law', 'formation of uniform law enforcement practice'.

Exclusive legal problem is about complex theoretical and legal issue in criminal proceedings, deciding on which, in the opinion of a board of judges or a chamber of the court of cassation (but not a joint chamber), is advisable to implement at the highest level in the hierarchical structural division of the Supreme Court, given the necessity of assurance of court practice unity.

The existence of exclusive legal problems is caused by defects of legislation (gaps, collisions, inconsistencies in legal regulation, the misuse of blanket and referral rules, defects of conceptual and categorical framework, the indistinctness of linguistic structures, etc.) and the excessive use of estimated terms in legal acts. Outlined and other defects cause legal uncertainty. In order to overcome this, courts have to appeal for discretion in law enforcement. In its turn, such a judicial review leads to or may lead to differences in approaches to the understanding of essence and the application of legal rules. In such circumstances, it is possible to maintain unity and subsequently, the stability of court practice regarding typical legal situations only at the level of the highest body in the judicial system of Ukraine - the Supreme Court.

$29 \quad$ Law of the Republic of Estonia (n 11).

30 Code of Criminal Procedure of Italy (n 15).

31 T Paolo, Manuale di procedura penale. Quindicesima edizione (Giuffrè Editore 2014) 950.

32 Criminal Procedure Code of the Republic of Lithuania (n 13). 
Accordingly, an exclusive legal problem is a complex theoretical and applicative issue which is derived from the defects of legislation that creates legal uncertainty and for the assurance of uniform approaches to understanding and the correct application of rules of law in typical legal situations needs to be resolved at the level of the Supreme Court.

Upon that, according to pt. 5 of Art. $434^{1}$ of the CrPC of Ukraine, only one division of the Supreme Court - the Grand Chamber ${ }^{33}$ - has authorities to resolve an exclusive legal problem. However, in our view, the necessity to involve the Grand Chamber of the Supreme Court in resolving an exclusive legal problem should be linked solely to legal situations common to various kinds of jurisdictions - administrative, commercial, criminal and civil. For example, problems of the implementation of basic principles in relevant branches of law, general provisions of litigation, the recording of litigation, or appeals and review of judgements in appeal and cassation. At the same time, when an exclusive legal problem is limited to only one type of jurisdiction, it is appropriate to refer it for consideration to the joint chamber of the corresponding cassation court within the structure of the Supreme Court. It is advisable to make corresponding amendments in the legislation of Ukraine.

The highest national courts can develop the law in their judgments in a number of different ways:

a) by providing a more detailed explanation of the legal reasoning. A Supreme Court can develop the law by providing a more detailed explanation of its legal reasoning. By doing so, a Supreme Court in its judgment not only outlines its final legal conclusion ('that is how it is') but also includes the arguments that reveal how it arrived at that conclusion. Such a form of reasoning increases clarity and predictability as to how the Supreme Court will decide in other comparable cases;

b) by providing a broader than necessary formulation. A Supreme Court may also formulate a legal rule in its judgment which is more extensive and more broadly applicable than strictly necessary to decide the case in question. Such a 'broader than necessary formulation' is often valuable for legal practice. It generally has a clear law-making effect, because a broadly formulated rule of this kind clarifies how decisions should be taken in a whole range of other - including future - cases;

c) by adding preceding paragraphs to describe general principles. The formulation of one or more broad legal rules in a judgment can be expanded by adding a description of general principles followed by the Supreme Court when deciding cases in this category. Such a formulation of general principles usually occurs in one or more preceding paragraphs in the judgment, before the court applies these principles to the present case. In such paragraphs, the court describes in general terms the legal framework which it adopts when judging cases of this kind;

d) by adding superfluous statements to their rulings. Some Supreme Courts from time to time add superfluous statements to their rulings. These are statements that do not influence the decision in the case at hand, and which, as a consequence, need not be included in the judgment. With this technique, the court calls for additional 'broadcasting time', as it were. It can be used when the court knows or foresees, from its contact with society and legal practice, that the issue is leading or will lead to controversy. If this technique is used, it is limited to matters which to some extent are related to the subject of the case in which the judgment is made. Otherwise, it would result in regulation with no genuine link to adjudication. ${ }^{34}$

By figuring out and overcoming defects of legal regulation, while assuring the unity of court practice, the Supreme Court influences the development of law by incorporating uniform

33 Code of Ukraine (n 4).

34 Feteris (n 9) 159-161. 
rules into law enforcement. It follows that the concept of 'an exclusive legal problem' is closely related to adjoining categories, referred to part 5 of Art. $434^{1}$ of the CrPC of Ukraine - the 'development of law' and the 'formation of uniform law enforcement practice. ${ }^{35}$

In our opinion, the development of law is a process of qualitative and quantitative changes in the legal system aimed at improving the latter. Instead, the formation of uniform law enforcement practice should be understood as an activity of creating predictability and consistency in the order of the hearing of similar categories of court cases and their results, which entails the similarity (sameness) of interpretation, a specification of legal norms, the overcoming of gaps in legal regulation by applying of analogy, and which is based on principles of substantive and procedural law.

The definition of the uniform application of the law is not formulated in Ukrainian legislation. However, according to CCJE, by common understanding, the concept appears as a compliance of regulations issued by governmental bodies, enterprises, institutions, organizations and officials with the Constitution of Ukraine and existing laws. ${ }^{36}$

The Supreme Court is responsible for ensuring uniform application of laws by the courts. The main instruments for implementing this competence are the principal standings and the principal legal opinions, which the Supreme Court considers and approves at a general session. Namely, it determines principal standings and principal legal opinions on issues of importance to ensure consistency in the application of the laws by the courts, on its own initiative or on the initiative by the meetings of judges or court departments. ${ }^{37}$

In items 5, 6, 20 and 28 of the Opinion № 20 (2017) of CCJE it is stated that the uniform application of the law is essential for the principle of equality before the law. Uniform application of the law contributes to public confidence in the courts and enhances the public perception of fairness and justice. The Supreme Court must ensure the uniformity of case law so as to rectify inconsistencies and thus maintain public confidence in the judicial system. In the CCJE's view, the public role of a Supreme Court, which consists of providing guidance pro futuro thus ensuring the uniformity of case law and the development of law, should be achieved through a proper filtering system of appeals. While admitting that such instruments can have a positive impact on the uniformity of case law and legal certainty, the CCJE is of the opinion that they raise concerns from the viewpoint of the proper role of the judiciary in the system of separation of state powers. ${ }^{38}$

The Grand Chamber of the Supreme Court, by reference to its task to assure the same (more precisely, the correct) application of rules of law by cassation courts (para 1, pt. 2 of Art. 45 of the Law of Ukraine 'On the Judiciary and the Status of Judges ${ }^{39}$ ) is intended in its judgements to guide in one direction not only court practice of local and appellate courts, but also of cassation courts (including their divisions - joint chambers, chambers and boards) on controversial law enforcement issues. Therefore, legal positions of the Grand Chamber of the Supreme Court have certain peculiarities. First of all, they are aimed at the coordination of legal approaches of boards of judicial chambers, as well as the judicial chambers of the Cassation Criminal Court themselves, that is they aim to overcome differences in understanding of certain issues of criminal and criminal procedural law which arise in

\footnotetext{
$35 \quad$ Code of Ukraine (n 4).

36 Questionnaire for the preparation of the Consultative Council of European Judges Opinion No 20 (2017): 'The role of courts with respect to uniform application of the law' $<$ https://rm.coe.int/16806fle 5b $>$ accessed 23 December 2020.

37 J Ristik, 'The Role of the Supreme Court in Ensuring Uniformity of Court Practice in The Republic of Macedonia'. (2017) XLI (2) Annual of Institute for Sociological, Political and Juridical Research 57: 61.

38 Opinion No 20 (2017) (n 2).

39 Law of Ukraine (n 19).
} 
the course of law enforcement activity. Secondly, they appear as a compromise solution to a problematic legal situation, a result of an analytical reflection of opinions of judges of different structural divisions of the highest authority in the judicial system of Ukraine.

At the same time the phrase of pt. 5 of Art. $434^{1}$ of the CrPC of Ukraine 'formation of uniform law enforcement practice' extends to both cases of referral of criminal proceeding for consideration by a higher structural division of the Supreme Court, since the main task of this judicial authority in accordance with pt. 1 of Art. 36 of the Law of Ukraine 'On the Judiciary and the Status of Judges' is to assure stability and unity of court practice. ${ }^{40}$ In terms of legal technique rules, the above mentioned provision does not appear to carry a meaningful burden and is therefore unnecessary.

Upon that, in the first instance, it is the responsibility of corresponding structural divisions of the Supreme Court to refer criminal proceedings (in parts 1, 2, 3 and 4 of Art. $434^{1}$ of the CrPC of Ukraine the word 'refers' is used) ${ }^{41}$ in the second instance, the reasonability of such a referral is left to discretion of the corresponding structural division of the Supreme Court - board of judges or chamber (in part 5 of Art. $434^{1}$ of the CrPC of Ukraine the phrase 'is entitled' is used). Taking into account the importance of the legal problem which is to be resolved and the consequences of such a resolution for law enforcement and law-making, establishing discretion, regarding the referral of criminal proceedings, is inappropriate.

\section{THE FAULT OF THE GROUNDS AND THE PROCEDURE FOR REFERRING THE CASE FOR CONSIDERATION TO A HIGHER-LEVEL STRUCTURAL DIVISION OF THE SUPREME COURT IN THE UKRAINIAN CRIMINAL PROCEDURE CODE}

Amendments to the CrPC of Ukraine made by articles $434^{1}, 434^{2}$ deserve critical appraisal.

First of all, they are capable of generating run-around - even before the start or during a cassation hearing as the criminal proceeding may be referred to another division of the Cassation Criminal Court of the Supreme Court. This, in its turn, is contrary to the principle of procedural economy because an irrational method of realization of criminal proceeding is chosen, which is characterized by long duration and a more costly achievement of tasks in a particular proceeding. This also shows subjectivity in deciding which judicial unit of cassation instance shall administer judicial control over justice of appealed judgment. The legal situation is further complicated by the authority of the Grand Chamber to return criminal proceedings referred to it to the lower structural division of the Cassation Criminal Court of the Supreme Court.

Secondly, the analysed novelties do not correlate with the principle of reasonableness of terms of a criminal proceeding. After the criminal proceeding has been referred for consideration to the chamber, joint chamber or the Grand Chamber of the Supreme Court, the cassation hearing becomes prolonged for an indefinite period. In addition, making such a decision after the beginning of a cassation hearing is related to its postponement. However, the postponement of a cassation hearing in such a case undermines, to the essence, such a criminal procedural institute because it is not related to an existence of obstacles which cannot be eliminated in this court hearing.

Thirdly, the criteria for the referral of criminal proceedings to consideration of the higher division of the Cassation Criminal Court of the Supreme Court and criteria for denial of its

$40 \quad$ Law of Ukraine (n 19).

41 Code of Ukraine (n 3). 
acceptance are of a subjective nature, since they focus on feasibility and consideration, rather than on the needs of legal regulation and law enforcement activity.

The procedure for referring a criminal case is much more effectively regulated in the criminal procedure legislation of Italy. Thus, according to part 2 of Art. 610 of the Code of Criminal Procedure of Italy the president of the Court of Cassation, either upon request of the Prosecutor General or the lawyers, or of his own motion, shall assign the appeal to the Court of Cassation to the Joint Chambers when the issues raised are particularly relevant or when conflicts among the decisions of individual chambers need to be solved. ${ }^{42}$ In addition, in part 1 of the Art. 618 of the Code of Criminal Procedure of Italy is stated that should a chamber realize that the question of law under its examination has caused or may cause judicial conflict, it may, upon request of the parties or of its own motion, refer the appeal to the Joint Chambers of the Court of Cassation, by issuing an order. ${ }^{43}$ In this way, it is possible not only to prevent but also to eliminate the existing judicial conflict between the decisions of the chambers.

Fourthly, the provisions of Art. $434^{1}$ of the $\mathrm{CrPC}$ of Ukraine have established conditions for both the abuse by parties of their procedural rights and self-withdrawal of the board, judicial chamber or joint chamber from performance of the duties assigned to them. The Ukrainian legislator practically encourages the inactivity of the relevant division of cassation instance in the form of transfer of criminal proceedings for consideration to its higher structural division. A voluntary waiver of these divisions of court of cassation instance from their obligations helps to avoid liability for possible negative consequences of their judgements. This approach obviously does not correlate with the principle of publicity in criminal proceedings.

Fifthly, the method of maintaining the unity of court practice set out in articles $434^{1}, 434^{2}$ of the CrPC of Ukraine is 'manual' and peculiar for the unstable regime of functioning of the judicial system. It may help to achieve positive results in a short-term perspective but for the long term forecast it will be smoothed down by negative occurrences in court practice. This method involves several subjects that produce legally significant decisions, creates a practice of administration of judicial control by structures of the Supreme Court higher by hierarchy, thereby unbalancing criminal procedural relations between interested persons and lower divisions of the highest body in the judicial system - the board of judges of cassation instance.

In our opinion, the coordination of the unified position of structural divisions of the Supreme Court in criminal proceedings should not be an element of the procedural form of the cassation proceeding but should be subject to the organizational and functional activity of this judicial body, regulated at the level of its internal acts.

\section{THE REASONABLENESS OF THE CRIMINAL PROCEEDING REFERRAL FOR CONSIDERATION TO THE JOINT CHAMBER AND THE GRAND CHAMBER OF THE SUPREME COURT}

The reasonableness of the referral and the consideration of criminal proceedings by the aforementioned judicial divisions of the Supreme Court raise substantial interest, taking into account the fact that the normative meanings of the categories 'similar legal relations' and 'an exclusive legal problem' are not defined.

As of today, about thirty judgments in the sphere of criminal procedure law have been

$42 \quad$ Code of Criminal Procedure of Italy (n 14).

43 Code of Criminal Procedure of Italy (n 14). 
made by the joint chamber of the Cassation Criminal Court and the Grand Chamber of the Supreme Court upon the results of cassation hearings.

Such judgments were studied from the perspective of such a requirement as reasonableness. In particular, the reasonableness of chosen judgements of the Supreme Court was evaluated on a three-level scale - complete, partial and insufficient. Special attention was paid to arguments used for the referral of criminal proceedings for the consideration of higher judicial divisions of the Supreme Court and to their relevance (propriety). Relevance of arguments was evaluated by three indicators - fully relevant, partly relevant and also irrelevant.

First of all, it should be pointed out that there is no unity in judicial divisions of the Supreme Court on an understanding of the meaning of the term 'similar relations' which, without doubt, significantly complicates its fulfilment of the task of maintaining the consistency and unity of court practice.

The partial reasonableness of decisions of boards of judges of judicial chambers of the Cassation Criminal Court on referral of criminal proceeding to the Grand Chamber of the Supreme Court was demonstrated by the fact that they did not always contain sufficiently convincing arguments for motivation of existence of a reason for making this decision.

For example, the decision of the judges as of 2 April 2018 contains internal contradictions since the board of judges while dismissing the opening of the cassation proceeding simultaneously decided to refer the criminal proceeding for the consideration of the Grand Chamber of the Supreme Court. ${ }^{44}$

Besides that, partial motivation of decisions of boards of Cassation Criminal Court judicial chambers to refer a case to the Grand Chamber of the Supreme Court was also shown in the fact that these court decisions do not always take into account the specificity of the circumstances of criminal proceedings which may influence the motives that explain the necessity of the consideration of criminal proceedings by the Grand Chamber of the Supreme Court.

For example, the judges acknowledged the necessity of the referral of criminal proceedings on both grounds. With respect to one of them, the decision specified that the absence of explanation by the court to the accused of the right of a jury during a preparatory hearing cannot be an absolute ground for a cancellation of judgements. Instead, the Supreme Court of Ukraine states that non-compliance of the court with the requirements of Art. 384 of the CrPC of Ukraine is an absolute ground for a cancellation of judgements by higher courts. It is important to notice the difference between the legal situation considered by the Supreme Court of Ukraine and the one which was received for consideration of the board of judges of the Cassation Criminal Court of the Supreme Court. In the first case, the prosecutor did not explain to the accused the possibility and the peculiarities of the hearing of the criminal proceedings against him by jury and did not attach a corresponding written explanation to the indictment act and the register of pre-trial investigation materials. During the proceeding, the court of the first instance not only failed to correct these defects but also violated pts. 1 and 2 of Art. 384 of the CrPC of Ukraine as long as it did not explain to the accused his right to hear the case by the jury and the specificity of such a proceeding. This means that the right to have the criminal case by jury was not explained to the accused at all. Instead of this, in the criminal proceedings which was the subject of consideration of the board of judges of the Cassation Criminal Court of the Supreme Court during a preparatory hearing the court, in the first instance, did not explain to the defendant this right and did not clarify his opinion in this regard. However later, when the prosecution was changed during the trial and the accused were charged with the crime under pt. 2 of Art. 115 of the

44 The decision in case No 51-3680ск18 (Cassation Criminal Court as a part of the Supreme Court, 02 April 2018). 
Criminal Code of Ukraine, the court of the first instance explained to them both the right to hear their case by jury. Therefore, in such a manner, a previously made substantial breach of requirements of criminal procedure law was corrected. In this situation not explaining the right to have the jury trial to the accused at the stage of the preparatory proceeding is a conditional reason for the cancellation of the sentence. ${ }^{45}$

There are no identified examples of insufficient motivation of the decisions of boards of judicial chambers of Cassation Criminal Court on referral of case for consideration by the Grand Chamber of the Supreme Court on the analysed ground.

The partial relevance of arguments in decisions of boards of the judicial chambers of the Cassation Criminal Court on the referral of criminal proceeding for consideration by the Grand Chamber of the Supreme Court appeared in fact that in motivating part of some of these court decisions along with the proper means of argumentation there were used theses which were non-relevant to legal situation that were considered by the court of cassation instance.

Thus, in the decision of the board of judges of the second judicial chamber of the Cassation Criminal Court as of 5 July 2018 the following means of argumentation were used: 1) rules of the CrPC of Ukraine; 2) Art. 6 of the European Convention on Human Rights (hereinafter ECHR); 3) provisions of the Instruction on organization of investigative (searching) actions conduction and the use of their results in criminal proceedings, approved by the Order of the General Prosecutor of Ukraine, Ministry of Internal Affairs of Ukraine, Security Service of Ukraine, the Administration of the State Border Service of Ukraine, the Ministry of Finance of Ukraine, the Ministry of Justice as of 16 November 2012;4) the court ruling of the Supreme Court of Ukraine as of 16 March 2017 in case № 5-364Kc16 which states that non-disclosure by parties of materials under procedure established in this article is a separate basis for recognition of such materials as inadmissible evidence; 5) the judgment of the Constitutional Court of Ukraine № 12pח/2011 as of 20 October 2011 which states that only actual data obtained in accordance with requirements of criminal procedure legislation may be legitimated and used as evidence in criminal cases; 6) the judgment of ECtHR as of 24 November 2000 in the case of Daktaras vs. Lithuania which states that admissibility of evidence is a matter for national courts and judgment of the ECtHR as of 26 March 1996 in the case Doorson vs. Netherlands which states that the right to open corresponding evidence is not an absolute right. From the means mentioned above, the rules of the CrPC of Ukraine and the provisions of instruction on the organization of investigative (searching) actions conduction and the use of their results in criminal proceedings are completely relevant to the legal situation that was the subject matter of cassation revision. Instead of this, decisions of the Supreme Court of Ukraine, the Constitutional Court of Ukraine and the ECtHR are partly relevant because they formulate legal positions on issues that are only indirectly related to the case under consideration. In turn, the reference to Art. 6 of the ECHR shall be admitted as an irrelevant means of motivation as there are no rules which have at least some connection to the analysed legal situation. ${ }^{46}$

The partial reasonableness of court rulings of the Grand Chamber of the Supreme Court lies in fact that while recognizing the very fact of existence of complex theoretical and applicative issues which need to be resolved at the level of the highest structural division of the Supreme Court a judgment on the consequences of a cassation hearing formulates a legal position on resolving only one of such issues. Instead of this, another issue is not resolved.

For example, in a court ruling as of 12 September 2018, the Grand Chamber of the Supreme Court, along with the necessity to partially deviate from the conclusion of the Supreme Court

$45 \quad$ The decision in case No 523/6472/14-к (Cassation Criminal Court as a part of the Supreme Court, 05 June 2018).

46 The decision in case No 751/7557/15-к (Cassation Criminal Court as a part of the Supreme Court, 05 July 2018). 
of Ukraine, recognized the existence of an exclusive legal problem regarding the application of a preventive measure at the stage of the cassation proceeding, not in general, but in the context of a specific case referred for its consideration. At the same time, this court ruling contains information neither about the essence of such a problem, nor about its reasons. Moreover, the Grand Chamber of the Supreme Court did not investigate ways of resolving such an exclusive legal problem since, under the consequences of cassation proceedings, the sentence was not cancelled, and the criminal proceeding was not submitted for a new trial in a court of lower instance. On the other hand, with regard to the existence of procedural authorities of the cassation court to examine evidence which was not submitted by the parties to courts of the lower instance, the Grand Chamber of the Supreme Court did not recognize it as an exclusive legal problem. However, this did not prevent it from formulating conclusions on the application of rules of law in this situation. ${ }^{47}$

According to the results of the conducted research there were no revealed cases of partial or insufficient reasonability of court rulings of the Grand Chamber of the Supreme Court on grounds of necessity to deviate from the conclusion on the application of the rule of law in similar legal relations set out in previously adopted judicial decisions of the Supreme Court of Ukraine or the Supreme Court, as well as the partial relevance or irrelevance of arguments used in court rulings. Similarly, the examples of partial or insufficient argumentation in the decision of the Supreme Court on the return of criminal proceedings for reconsideration as well as the partial relevance and irrelevance of arguments used therein were not found.

Most decisions on the referral of the criminal proceeding to be considered by the Grand Chamber of the Supreme Court and court rulings of the Grand Chamber of the Supreme Court on the results of cassation hearing contain a partial motivation of the existence of an exclusive legal problem.

Such a statement derives from the fact that judgments of the Supreme Court do not formulate features and meaning of an exclusive legal problem and do not analyse reasons for its occurrence. In addition, judgments which were examined do not provide an interpretation of the term 'an exclusive legal problem,' as well as categories related with it the 'development of law' and the 'formation of uniform law enforcement practice' which complicates the understanding and the application of corresponding rules of criminal procedure law (articles $434^{1}, 434^{2}$ of the CrPC of Ukraine)..$^{48}$

It is fair to say that in the decision of the Grand Chamber of the Supreme Court on taking a cassation proceeding to consideration, the semantic meaning of term 'problem' has been disclosed and an approach has been outlined to the formulation of the definition of 'a legal problem' - 'contradictory situations characterized by opposite approaches to understanding of certain events, statuses, processes, occurrences or objects and which require formulation of recommendation or proposal that will allow to solve the corresponding problem. ${ }^{39}$

The partial reasonableness of decisions of boards of judges of the judicial chambers of the Cassation Criminal Court on referral of cases for consideration by the Grand Chamber of the Supreme Court, in our opinion, has been manifested in the fact that some of them lack clear, evident and convincing arguments for the necessity of making such a decision.

For example, in the decision of the judges as of 6 March 2018 there is no formulation of the meaning of an exclusive legal problem. It is unclear whether it should be considered as a failure by investigating judges to comply with requirements of criminal procedural law by an overreaching of their authorities, or whether such a problem consists in contradiction

47 The decision in case No 523/6472/14-K (n 44).

48 Code of Ukraine, (n 4).

49 Decision in case No 243/6674/17-к (Grand Chamber of the Supreme Court, 12 April 2018). 
to appellate and cassation practice, or for both reasons. Moreover, the board of judges did not express itself clearly concerning any support or disapproval of the legal position of the Supreme Court of Ukraine set out in the court ruling as of 12 October 2017.50

An insufficient argumentation of decisions of boards of judges of judicial chambers of the Cassation Criminal Court on referral of case for consideration by the Grand Chamber of the Supreme Court was expressed in an abstractive summary of the legal situation which was the subject matter of a cassation hearing without formulation of its own legal position and therefore the grounds for the hearing of criminal proceedings by the Grand Chamber of the Supreme Court.

For example, the judges in the decision as of 6 March 2018 retold how the Supreme Court of Ukraine in its court ruling as of 12 October 2017 mentioned that in a case of making by an investigating judge a decision which is not provided by criminal procedural rules to which refer provisions of part 3 of Art. 309 of the CrPC of Ukraine, the court of appeal is not entitled to refuse checking its legality, appealing to provisions of part 4 of Art. 399 of the $\mathrm{CrPC}$ of Ukraine. The right to appeal such judgment is subject to securing it on the basis of item 17 of part 1 of Art. 7 and part 1 of Art. 24 of the CrPC of Ukraine, which guarantee it.

But then the judges of the Supreme Court have drawn another conclusion, that the decision of the investigating judge, on appointment of unscheduled documentary inspection on compliance with requirements of tax, currency and other legislation, is not subject to appeal because such kind of a decision is not included in the list provided by part 1 of Art. 309 of the $\mathrm{CrPC}$ of Ukraine. From the abovementioned legal positions, it is evident that the judges, in fact, deviated from the previously formulated conclusion of the Supreme Court of Ukraine. However, the judges took a neutral position - neither supporting nor disapproving the above conclusions. Moreover, it is not clear from this decision where exactly an exceptional legal problem is, the existence of which is stated by the board of judges, what its reasons are and why there is no unity of cassation practice. ${ }^{51}$

The partial relevance of various types of arguments in decisions of the judges of the Cassation Criminal Court on referral of a case to the Grand Chamber of the Supreme Court was manifested in the use of arguments which both concern and do not concern complicated theoretical and applicative issues which are subject matter of the cassation hearing.

Thus, in the decision of the judges the following grounds of motivation were used: 1) the rules of criminal procedural law of Ukraine which do not provide for the right of the investigating judge to make a decision about the authorization of unscheduled inspections; 2) an analysis of court practice which gave a possibility to state the wide extent of cases where investigative judges made decisions about permitting unscheduled inspections; 3) the study of the practice of courts of appeal instance when some reporting judges opened appeal proceedings on a complaint and others refused to do so on the grounds of which its contradiction is established; 4) investigation of cassation court practice which implies that cassation instance both leaves decision on the refusal to open appeal proceedings unchanged and annuls it with a return to the previous stage of criminal proceedings which does not contribute to a unity of court practice; 5) the provisions of Art. 8 of the ECHR content of which provides that unscheduled inspections could potentially lead to a breach of Art. 8 of the ECHR; 6) the legal position of the ECtHR from which it follows that by granting permission for an unscheduled inspection, an investigating judge acts not as judicial authority which prevents possible violations from the side of the investigating authorities, but in fact, initiates such an inspection giving an investigator or prosecutor powers which the law does not empower

$50 \quad$ Ibid (n 48).

51 The decision in case No 237/1459/17 (Cassation Criminal Court as a part of the Supreme Court, 06 March 2018). 
them with; 7) provisions of the Constitution of Ukraine which outline the limits of state interference in the rights and freedoms of an individual; 8) Art. 36 of the Law of Ukraine 'On the Judiciary and Status of Judges' which determines powers of the Supreme Court in the court system of Ukraine; 9) the decisions of the ECtHR which express legal positions regarding the right of the supreme judicial authority to interpret legal rules and to make decisions which are not expressly provided by law. The last three grounds are not relevant as they do not concern the legal situation that was the subject matter of the cassation hearing. ${ }^{52}$

The irrelevance of different kinds of arguments in the decisions of the boards of judges of judicial chambers of the Cassation Criminal Court within the Supreme Court on referral of cases for consideration by the Grand Chamber on the aforementioned grounds was not established.

In our opinion, the partial reasonableness of court rulings of the Grand Chamber of the Supreme Court was expressed by the fact that they do not always formulate an independent legal position nor use their own arguments to confirm it.

In the court decision it is mentioned that in the case of making by the investigating judge a decision which was not provided by criminal procedural rules, and which refers to provisions of part 3 of Art. 309 of the CrPC of Ukraine, the court of appeal instance is not entitled to refuse to check its legality on the grounds of provisions of part 4 of Art. 399 of the CrPC of Ukraine. The right to appeal such a judgment shall be secured on the basis of item 17, pt. 1 of Art. 7 and part 1 of Art. 24 of the CrPC of Ukraine which guarantee it. However, it does not further interpret the wording of item 8 of Art. 129 of the Constitution of Ukraine which guarantees the right of appeal review and also the provisions of Art. 24 of the CrPC of Ukraine, which, in particular, guarantees the right to review by a court of a higher level a sentence, a court decision concerning rights, freedoms or interests of a person regardless of whether such person participated in the court hearing. ${ }^{53}$

The partial relevance of different kinds of arguments in court rulings of the Grand Chamber of the Supreme Court is expressed in the fact that inappropriate reference to provisions of the ECHR occurs sometimes.

Namely, the means provided by the decision of the Supreme Court with reference to the provisions of Art. 8 of the ECHR do not appear to be relevant since this article guarantees the right to respect private and family life but the context of this criminal proceeding refers to public activity of the Limited liability company. Legal positions of the Constitutional Court of Ukraine, the ECtHR and the Supreme Court of Ukraine in relevant cases which were used in a court ruling of the Grand Chamber are partly relevant as they do not directly concern the legal situation which was the subject matter of the cassation review but outlines the general approach to limitations of rights on appeal. ${ }^{54}$

As a result of an analysis of decisions on the referral of criminal proceedings for consideration by the Grand Chamber of the Supreme Court and the decisions of the Grand Chamber of the Supreme Court under the consequences of a cassation hearing a situation was revealed in which two criminal proceedings with the same problematics - the lawfulness of decisions of investigating judges on the holding of unscheduled inspections and the possibility of appealing against these decisions - had reasoning for the existence of an exclusive legal problem, the necessity for its resolution at the level of the Grand Chamber of the Supreme Court, as well as the reasoning of the conclusion of the Grand Chamber itself which substantially differed in completeness. ${ }^{55}$

$52 \quad$ The decision in case No 243/6674/17-к, (n 48).

53 The decision in case No 237/1459/17 (n 50).

54 The decision in case No 243/6674/17-K (n 48).

55 The decision in case No 243/6674/17-K (n 47); The decision in case No 237/1459/17 (n 50). 
In conclusion, let us focus on the analysis of the reasonableness of decisions of boards of judges of judicial chambers of the Cassation Criminal Court on referral of criminal proceeding for consideration by the joint chamber of this structural division of the Supreme Court, as well as judgments of the joint chamber upon results of hearing.

For example, in the decision of the judges on case referral for consideration by the joint chamber of the Cassation Criminal Court, conclusions provided by the decision of the Grand Chamber of the Supreme Court as of 23 January 2019 were not taken into account. Although this judgment concerns the possibility of appeal in the cassation of amnesty judgments, it does set out conclusions on appeal in the cassation of judgments on a stage of the enforcement of judgments in general. Thus, item. 43 of this decision points out that, based on the provisions of item 8 of Art. 129 of the Constitution of Ukraine in wording as of 2 June 2016, the right of a person to appeal in cassation against a judgment in criminal proceedings has a limited nature and may be realized only in cases provided by the CrPC of Ukraine. In item 40 of the same judgment, it is emphasized that Art. 539 of the CrPC of Ukraine does not provide the possibility of the cassation review of judgments made at the stage of the enforcement of a court sentence. Taking into account these legal rules, the board of judges of the second judicial chamber of the Cassation Criminal Court could quite independently and without the referral of the criminal proceeding for consideration by the joint chamber of the Cassation Criminal Court make a decision on the possibility of appeal in the cassation of decision about the cancellation of the release of those convicted from the service of the sentence with probation. ${ }^{56}$

\section{CONSISTENCY OF COURT PRACTICE OF THE STRUCTURAL DIVISIONS OF THE SUPREME COURT}

Legal positions established by the Supreme Court in the sphere of criminal proceedings do not have a stable nature and are sometimes contradictory. We will provide some examples of cases in which the Supreme Court decided on criminal cases in contradiction to its own legal position formulated in a similar case.

Thus, in the decision it is mentioned that carrying out the inspection of housing does not require the decision of an investigating judge. ${ }^{57}$

An opposite legal opinion on this issue was expressed by the judges - if an event which is the reason for an inspection, happened in housing or in another possession of a person, the requirements provided by Art. 30 of the Constitution of Ukraine and the relevant provisions of articles 13, 233, 234 and 237 of the CrPC of Ukraine shall be applied to the carrying out of such an inspection. ${ }^{58}$

Apparently, at the level of the Criminal Cassation Court within the Supreme Court there is no unity regarding the question of whether the decision by an investigative judge is required for an inspection of the scene in housing or another possession of a person. In this case, the Supreme Court did not assure the stability and unity of court practice as is required by part 1 of Art. 36 of the Law of Ukraine 'On the Judiciary and the Status of Judges. ${ }^{5}$ '

56 The decision in case No 756/9514/15-к (Cassation Criminal Court as a part of the Supreme Court, 14 February 2019).

57 The decision in case No 752/17016/16-К (Cassation Criminal Court as a part of the Supreme Court, 01 February 2018).

58 The decision in case No 159/451/16-K (Cassation Criminal Court as a part of the Supreme Court, 12 February 2019).

59 Law of Ukraine (n 19). 
Following the legal positions which contain differences with the previously formulated conclusions on the application of rules of law - the decision of an investigating judge on the full or partial cancellation of an arrest of the property made under the rules of Art. 174 of the $\mathrm{CrPC}$ of Ukraine is not subject to appeal, ${ }^{60}$ an appeal against the decision of an investigating judge on the complaint submitted in an order established by Art. 206 of the CrPC of Ukraine is not provided by the law. ${ }^{61}$ The motivation of such legal positions is based on the fact of an absence of these decisions of investigating judges in the list of court decisions that may be appealed (Art. 309 of the CrPC of Ukraine).

While formulating these legal positions the joint chamber of the Criminal Cassation Court should have taken into consideration the legal position of the Grand Chamber of the Supreme Court set out in the decision ${ }^{62}$ and in the decision ${ }^{63}$ which state that the decisions of investigating judges concerning the authorization of unscheduled inspections can be appealed regardless of the fact that such decisions are not mentioned in Art. 309 of the CrPC of Ukraine. In this case, according to the authors, the joint chamber of the Cassation Criminal Court has neglected the already formulated court practice of the Grand Chamber of the Supreme Court.

In our opinion, the position of the Grand Chamber of the Supreme Court expressed in the decision as of 16 October 2019 is also contradictory - if the prosecution, during the pre-trial investigation, took time with all the necessary and possible measures aimed at the disclosure of procedural documents which became the grounds for conducting unspoken investigative (search) actions but such documents were not disclosed for the reasons which did not depend on the will and procedural behaviour of the prosecutor, the court may not automatically recognize the reports of unspoken investigative (search) actions as inadmissible evidence on the motives of the non-disclosure of procedural documents which sanctioned their conduct.

In fact, by this legal position, the Grand Chamber of the Supreme Court stepped back from the position previously formulated by it in its court ruling as of 16 January 2019 - the procedural documents which became the grounds for conducting unspoken investigative (search) actions and which were not disclosed to the defence party in accordance with the procedure laid down by Art. 290 of the CrPC of Ukraine may be open to another party since they were not in the possession of prosecution at that time, but the court shall not admit the information contained in these materials of criminal proceedings as evidence.

As indicated in p. 31 of Opinion 20 (2017) of the CCJE 'On the Role of Courts with Respect to Uniform Application of the Law', the deviation from produced court practice should only be made if there is an urgent need. ${ }^{64}$ However, such a need has not been explained by the aforementioned structural divisions of the Supreme Court.

\section{CONCLUSIONS}

One of the ways in which the highest national courts can ensure the unity and sustainability of judicial practice is by referring a criminal case to the highest division of the Supreme Court. Structural divisions of the Supreme Court play a crucial role in the equal application of the court practice, a provision of its stability.

60 The decision in case No 569/17036/118 (Cassation Criminal Court as a part of the Supreme Court, 19 February 2019).

61 The decision in case No 766/22242/17 (Cassation Criminal Court as a part of the Supreme Court, 27 May 2019).

62 The decision in case No 243/6674/17-к (n 48).

63 The decision in case No 237/1459/17 (n 50).

64 Opinion No 20 (2017), (n 2) items 6, 20. 
Some European countries have fixed the grounds and procedure for such a referral in their criminal procedure legislation. The Ukrainian legislator has borrowed legal regulation of this issue, while establishing a number of national features.

The wording of articles $434^{1}, 434^{2}$ of the CrPC of Ukraine which establishes grounds and a procedure of referral of criminal proceedings for consideration by the corresponding structural divisions of the Supreme Court is not only not free from defects associated with compliance to requirements of legislative technique and doctrinal justification but also represents the introduction of a 'manual' method of maintaining the unity of court practice which is peculiar for an unstable regime of functioning of the judicial system.

In general, the level of reasonableness of judgments by the Supreme Court on the referral of criminal proceeding for consideration by the higher judicial division is quite high but, in some respects, it still requires improvements. Firstly, the Grand Chamber of the Supreme Court has to clarify the meaning of categories 'similar legal relations' and 'an exclusive legal problem. Secondly, in the decisions of the boards of judges of the judicial chambers of the Criminal Cassation Court on the referral of criminal proceedings for consideration by the Grand Chamber of the Supreme Court, it is reasonable to bring forward more convincing arguments for the justification of the existence of the grounds for reaching this decision and to use only a relevant means of argumentation in their motivating $\mathrm{p}$ Thirdly, the boards of judges of the judicial chambers of the Criminal Cassation Court should check whether the Grand Chamber of the Supreme Court has already formulated the conclusion regarding similar legal situations before deciding to refer the criminal proceeding for consideration by the joint chamber of this court. Fourthly, the Grand Chamber of the Supreme Court in court rulings on the consequences of the cassation review should provide legal positions on all complex theoretical and applicative issues which need to be resolved at the level of the highest judicial division of the Supreme Court using its own evidence for its substantiation.

The provisions of the criminal procedural legislation of Ukraine and the activity of the Supreme Court have not assured the absence of differences and contradictions in law enforcement. It is not uncommon in the activity of the Supreme Court that one of its structural divisions becomes a source of uncertainty and of contradiction in court practice instead of the assurance of its unity. Therefore, the implementation of the principle of legal certainty (res judicata) and the doctrine of the stability of justice (jurisprudence constante) in Ukraine is far from optimal.

\section{CONTRIBUTORS}

All the coauthors read, approved the final version and agreed to be accountable for all aspects of this article.

Nazar Bobechko is a Dr. Sc. (Law), Prof. of the Department of Criminal Procedure and Criminalistics, Ivan Franko National University of Lviv, Ukraine. Member of the Scientific Advisory Board of the Supreme Court. Member of the Scientific Advisory Board of the State Bureau of Investigation. Member of the Specialized Academic Council of Ivan Franko National University of Lviv. USAID project participant "Analysis of the case law of the Supreme Court" (2019-2020).

https://orcid.org/0000-0001-9304-3170

nazar.rost@gmail.com

Alona Voinarovych is a PhD (Law), Assoc. Prof. of the Department of Criminal Procedure and Criminalistics, Ivan Franko National University of Lviv, Ukraine. Participant in the international project "Sommerschule Europaisches Recht". Scientific interest is the participation of the people in criminal proceedings, problems of modern criminal proceedings, international standards for the protection of participants in criminal proceedings, public trial of criminal proceedings.

https://orcid.org/0000-0003-3474-377X

alyonavoinarovych@gmail.com 
Volodymyr Fihurskyi is a PhD (Law), Assoc. Prof. of the Department of Criminal Procedure and Criminalistics, Ivan Franko National University of Lviv, Ukraine. Participant in international projects "Training on alternative dispute resolution as an approach to ensuring human rights" (TEMPUS IV TRADIR) and "Sommerschule Europaisches Recht". Research interests: problems of criminal procedure and criminology (in particular, forensic tactics and methods), general and legal psychology.

https://orcid.org/0000-0002-5329-8985

figurskyvm@gmail.com

\section{REFERENCES}

Giardullo C, 'Four Years After: The "Long March" of Justice-Sector Reforms in Ukraine'. 1 (18) Istituto Affari Internazionali Papers (2018), 1-24 <https://www.iai.it/sites/default/files/iaip1801.pdf> accessed 23 December 2020.

Criminal Procedure Code of the Republic of Lithuania of 14 March 2002 № IX-785 "Lietuvos Respublikos baudžiamojo proceso kodekso" <https://e-seimas.Irs.lt/portal/legalAct/en/TAD/ TAIS.163482> accessed 23 December 2020.

Ambrasienè Dangute and Cirtautienè Solveiga, 'The Role of Judicial Precedent in the Court Practice of Lithuania', 2(116) Jurisprudencija (2009), 61-78.

Esplicato Codice Di Procedura Penale. XVIII edizione. (Edizioni Giuridiche Simone, Napoli 2013).

Ristik J, 'The Role of the Supreme Court in Ensuring Uniformity of Court Practice in The Republic of Macedonia'. XLI(2) Annual of Institute for Sociological, Political and Juridical Research (2017), 57-67.

Laffranque J,'The Judicial System of Estonia and European Union Law', 33(2) International Journal of Legal Information (2005), 224-239.

Baccaglini L, di Paolo G, Cortese F, 'Judicial Precedent in the Italian Legal System: A Shift Toward a Stare Decisis Model?', Stanford Law School Chine Guiding Cases Project (2017), 1-16, <https://cgc.law. stanford.edu/wp-content/uploads/sites/2/2017/04/CGCP-English-Commentary-19-Baccaglini-DiPaolo-Cortese.pdf> accessed 23 December 2020.

Longman Dictionary of American English, spec. ed. (Pearson Education Limited, Harlow 2009).

Feteris M, 'Development of the Law by Supreme Courts in Europe'. 13(1) Utrecht Law Review (2017), 155-169.

Zhernakov M, 'Judicial Reform in Ukraine: Mission Possible?' (2016), 1-12 <http://en.dejure. foundation/library/judicial-reform-in-ukraine-mission-possible> accessed 23 December 2020.

Opinion № 20 (2017) of Consultative Council of European Judges (CCJE) “The Role of Court with the Respect to the Uniform Application of the Law" <https://rm.coe.int/opinion-no-20-2017-on-therole-of-courts-with-respect-to-the-uniform-a/16807661e3> accessed 23 December 2020.

Opinion of European Commission for Democracy through Law on Draft Law of Ukraine on the "Judicial System" (CDL (2001) 46) <http://www.venice.coe.int/webforms/documents/default. aspx?pdf=CDL(2001)055-e\&lang=RU\#> accessed 23 December 2020.

Nitsova S, Pop-Eleches G, Robertson G, 'Revolution and Reform in Ukraine. Evaluating Four Years of Reform', Institute for European, Russian and Eurasian Studies at the George Washington University's Elliott School of International Affairs (2018), 1-70 <https://www.ponarseurasia.org/perspectives/ revolution-and-reform-ukraine-evaluating-four-years-reform> accessed 23 December 2020.

Paolo T, Manuale di procedura penale. Quindicesima edizione. (Giuffrè Editore, Milano 2014).

Code of Criminal Procedure of Italy of 22 September 1988 № 477 "Codici di procedura penale" (as amended of 25 June 2020) <https://www.brocardi.it/codice-di-procedura-penale/> accessed 23 December 2020.

Code of Ukraine of 13 April 2012 № 4651-VI "Criminal Procedure Code of Ukraine" (as amended of 21 July 2020) <https://zakon.rada.gov.ua/laws/show/4651-17\#Text> accessed 23 December 2020. 